\title{
Higher Education Henchmen: Vicarious Bullying and Underrepresented Populations
}

\author{
Leah P. Hollis Ed.D \\ Department of Advanced Studies \\ Leadership and Policy, Morgan State University
}

\begin{abstract}
This study is an original examination of the overlooked phenomenon of vicarious bullying in higher education. While researchers have brought attention to direct bullying, vicarious bullying-which results when a third party acts as the aggressor or henchman-can also create destructive environments that lead to employee disengagement and turnover. The findings reported in this analysis were obtained through a meta-analysis of 317 American institutions of higher education, thus including both four-year and two-year colleges. The purpose of this analysis was to consider the frequency of vicarious bullying as reported by the study participants. The participants invited to engage the instrument were from 317 colleges and universities. of these study respondents $35 \%$ of them $(n=197)$ reported being the target of vicarious bullying. Participants from underrepresented backgrounds involving race, gender, and sexual orientation also reported vicarious bullying with higher frequency than the $35 \%$ frequency reported from the general sample.
\end{abstract}

Keywords: workplace bullying, vicarious bullying, higher education

In history, powerful leaders have used third parties or henchmen to spread messages, amplify terror, or disseminate weapons. Henchman is an old English word retained by the Scottish to reflect on a personal attendant who is "an unscrupulous and ruthless subordinate, especially a criminal," or "an unscrupulous supporter or adherent of a political figure or cause, especially one motivated by person gain" (Dictionary 0, 2014). Strathern (1993) wrote, "These henchmen are not outsiders. They are kin to either the politicians or the local people whom they attempt to influence, .... . They receive money, vehicles, and business opportunities in return for promoting the cause of the politicians" (p. 7). Throughout history, the henchman has been a complex figure, used to magnify abuse from a tyrant or dictator. The henchman, while an extension of the powerful leader, is typically younger and/or less experienced, yet still carries the full weight of the leader's power. Steinacher (2012) referred to Adolf Hitler's Nazi war criminals as henchmen. These individuals formed a secret society to escape justice after World War II (Hughes, 2012). Feferman (2003) also referred to the Nazi war criminals as henchmen in his discussions of the USSR investigating the Nazis. Chitando and Togarase (2010) reflected on the Zimbabwe political crisis and how Mugabe used his henchmen to spread naked violence. According to Getty (2013), Stalin's henchmen were used to repress the community. Even Nixon's associates involved in the Watergate scandal were called henchmen due to their effort to interfere with the media during this scandal (Bernays, 2001). Historically, henchmen have been used to disseminate power and abuse, acting as an extension of the tyrant, dictator, or bully.

The association between vicarious bullying and the acts of henchmen in this analysis is in no way intended to trivialize the pain brought by the aforementioned dictators and tormenters. Instead, this association with historical henchmen aims to lend weight to the impact that 
workplace bullying has on the targets. In addition, this association should show the effect that henchmen as an extension of a bully's abusive power have on their victims.

Targets of workplace bullying who report direct and/or vicarious bullying often resort to employee disengagement or resignation from the job as a means of escape (Byrne, 2014). Targets of workplace bullying have also reported depression, sleeplessness, and other medical issues (Bond, et al., 2010; Rodríguez-Muñoz, et al., 2011; Thomas, 2005). Some of the respondents that took part in the Hollis (2016) study employed escape mechanisms, such as sick time, self-isolation and, in some instances, suicidal ideation. An abusive workplace bully can destroy the career and livelihood of targets.

With these complex dynamics in mind, this current analysis focused on the henchmen in higher education institutions and the reported vicarious bullying. The henchman or henchwoman can be a coordinator, an administrative assistant, or even a direct report to the bully. Typically, this subordinate figure to the bully is jockeying for power, a raise, a promotion, or influence, and serves as the bully's abusive extension. However, in other cases, the henchman may be a reluctant participant and a target as well.

Ryan (2016) commented that workplace bullying is a particularly intense management problem that destroys teamwork and collaboration. Recruiting other figures, or henchmen, further destroys the environment. To this point, a study participant from the four-year study remarked "Targets typically left within two years, and those in the 'in group' adopted the bullying behaviors of the department head, and even did some of the bully's bidding" (personal communication, 2012). Those who survived the environment became junior bullies. Once this study participant left his organization, several remaining staff would call him to cry about the horrible treatment they experienced (personal communication, 2012). However, the organization failed to recognize the boss as the bully; instead, leadership withstood the turnover and simply considered that those leaving "just couldn't take it." Workplace bullying and the questionable leadership that allows for such abusive conduct also creates psychologically unsafe work environments, which hurts employees (Erkutlu, \& Chafra, 2014).

For this analysis on vicarious bullying the following definition of workplace bullying was applied:

Harassing, offending, socially excluding someone, or negatively affecting someone's work tasks. This behavior occurs repeatedly and regularly over a period of time about six months. With the escalating process, the person confronted ends up in an inferior position and becomes the target of systematic negative social acts. (Einarsen, et al., 2011, p. 22).

The definition of vicarious bullying, when a henchman or henchwoman is sent to do the bullying, means that a third party performs the aforementioned actions (Einarsen, 2011). For the purpose of this analysis, the definition given above was modified to: a henchman or henchwoman is a bully's subordinate, sent to harass, offend, exclude, and negatively affect the target. The henchman or henchwoman utilizes vicarious bullying, on the behalf of the bully and with the bully's power, in order to place the target in a negative social position.

\section{PURPOSE OF THIS STUDY}

Workplace bullying can be difficult for human resources personnel to manage. While some Canadian provinces and the Scandinavian countries have prohibited bullying behavior (Hollis, 2016a), other countries do not have anti-bullying laws, or the organization does not have clear policy. Employees who report their experiences of workplace bullying bring complex stories, 
with years of abuse for the target (Hollis, 2016b). The workplace bullying problem becomes increasingly convoluted when the bully uses subordinates to implement abusive commands and directives on behalf of the bully.

\section{IMPACT ON THE HENCHMAN/HENCHWOMAN}

For a third person to engage in the bullying, that third party (henchman) would also have to suspend his or her empathy for the target. The bully, the person with power, is typically acting from a weakness or perceived threat, hence the bullying behavior. However, this third party is acting under the direction of the bully, due to which he/she must reduce the target to an object instead of embracing the target's humanity. In short, this henchman would engage in "low empathy [and] fail to alleviate the distress and discomfort of others" (Jolliffe \& Farrington, 2006, p. 540).

As the henchman/henchwoman is typically a subordinate, unfortunately, the bullying is training this third party to accept abuse as a leadership style. Consequently, that subordinate can adopt the view that abuse and coercion are viable leadership tools. Such bullying behaviors can continue, even when the initiating bully has left the organization. Without organizational leadership taking proactive steps in curtailing all types of bullying, the organizational culture can normalize abuse for employees, creating a costly behavior pattern.

\section{DESIGN/METHODOLOGY/APPROACH}

This study is based on a meta-analysis of existing data sets pertaining to workplace bullying in higher education. Potential respondents at 317 four-year colleges and universities, as well as two-year community colleges, received a 35-question instrument regarding workplace bullying in American higher education. The researcher had the instrument beta-tested by five faculty members and administration, all of whom had at least 15 years of experience in American higher education. The initial findings revealed that 62\% (Hollis, 2016) of respondents from four-year colleges and universities faced workplace bullying, while $64 \%$ of respondents from two-year schools reported bullying (Hollis, 2016a). This secondary analysis focused on a topic not yet reported, the phenomenon of vicarious bullying in American higher education.

\section{RESEARCH LIMITATIONS/IMPLICATIONS}

The findings reported in this paper emerged from participants' responses regarding working in American higher educations. All participants were asked to respond to the 35- question survey about their experiences in dealing with vicarious bullying. The analysis was performed under the assumption that the participants drawn from the 317 American institutions of higher education were honestly responding to the questionnaire.

\section{Central Research Question}

Higher education researchers have reported different tactics of bullying in higher education takes (Hollis, 2016; Keashly \& Neuman, 2010; Simpson \& Cohen, 2004). Some bullies are passive aggressive, and use the Internet to perpetrate cyber bullying, assign unfair tasks and deadlines, or even request minute-by-minute reporting of time (Hollis, 2016). These bullying tactics hurt the work productivity for targets and align with Einarsen et al.'s (2011) definition of bullying, which specifically infers with the target's work productivity. This study will extend the knowledge on workplace bullying to include an analysis of vicarious bullying, which takes place when a third party is sent to abuse or coerce the target. Five research questions were developed to analyze vicarious workplace bullying in American higher education. 
In addition to calculating the frequency of vicarious bullying for the general population, the researcher used demographic descriptors and created additional analyses in relationship to vicarious workplace bullying. The targets' demographic information was further analyzed in terms of race (Caucasian or people of color), gender (male vs. female), age ( $\geq 35 \mathrm{vs.} \leq 36$ ), and sexual orientation (heterosexual or member of the LGBTQ community). Therefore, the following research questions were developed:

RQ1 What is the frequency of vicarious bullying in American higher education?

RQ2 What is the difference in the frequency of vicarious bullying in American higher education based on race?

$\mathbf{H}_{2 \mathrm{I}}$ There is a difference in frequency of vicarious bullying based on race.

$\mathbf{H}_{20}$ There is no difference in frequency of vicarious bullying based on race.

RQ3 What is the difference in the frequency of vicarious bullying in American higher education based on gender?

$\mathbf{H}_{3 \mathbf{I}}$ There is a difference in frequency of vicarious bullying based on gender.

$\mathbf{H}_{30}$ There is no difference in frequency of vicarious bullying based on gender.

RQ4 What is the difference in the frequency of vicarious bullying in American higher education based on sexual orientation?

$\mathbf{H}_{4 \mathrm{I}}$ There is a difference in frequency of vicarious bullying based on sexual orientation.

$\mathbf{H}_{40}$ There is no difference in frequency of vicarious bullying based on sexual orientation.

RQ5 What is the difference in the frequency of vicarious bullying in American higher education based on age?

$\mathbf{H}_{5 \mathrm{I}}$ There is a difference in frequency of vicarious bullying based on age.

$\mathbf{H}_{50}$ There is no difference in frequency of vicarious bullying based on age

\section{FINDINGS}

As a part of the meta-analysis of data pertaining to vicarious bullying at American four-year colleges and universities and two-year community colleges, respondents were asked to answer the survey question, "In regard to VICARIOUS bullying (boss sends assistant or other staff to do his/ her bullying) have you been affected by vicarious bullying?" The responses to this survey question addressed RQ1-What is the frequency of vicarious bullying in American higher education? In response to this question, 197 of 557 respondents (35\% of the study sample) noted that they were affected by vicarious bullying. Table 1 shows the frequency of responses to this question, and responses once the participants were grouped by race, gender, sexual orientation, and age. See table 1. 
Table 1

\begin{tabular}{|lll|}
\hline \multicolumn{3}{|l|}{ Meta-analysis of Vicarious Bullying Targets } \\
All respondents & $35 \%$ & (197 of 557) \\
\hline People of color & $44 \%$ & (71 of 161 affected) \\
Caucasians & $32 \%$ & (126 of 396 affected) \\
\hline Women & $38 \%$ & (152 of 401 affected) \\
Men & $29 \%$ & (45 of 156 affected) \\
\hline Heterosexual & $34 \%$ & (173 of 510 affected) \\
LGBTQ & $51 \%$ & (24 of 47 affected) \\
\hline Age under 35 & $38 \%$ & (39 of 101 affected) \\
Age over 36 & $35 \%$ & (195 of 456 affected) \\
\hline
\end{tabular}

As 35\% of the study sample reported having experienced vicarious bullying, this issue is more prevalent among people of color (44\%), women (38\%), members of the LGBTQ community (51\%), and those under the age of 36 (38\%) faced higher frequencies of vicarious bullying than the general population. Table 1 also served as a contingency table showing the differences in the frequency of the phenomena by category. The analysis aimed at addressing the remaining research questions (RQ2-5) involved subjecting the data to chi-squared analysis to further examine the frequency of vicarious bullying among the participants when the sample was grouped by race, gender, sexual orientation, and age. For this purpose, a "yes" response was assigned a numerical value of 1 , while "no" was coded as 2. IBM SPSS for Macintosh was used to calculate the actual and expected count for each group.

The results of the chi-squared analysis pertaining to RQ2 "What is the difference is the frequency of vicarious bullying in American higher education based on race?" are reported in Table 2.

Table 2

Frequency of Vicarious Bullying among Targets of Different Racial Origin

\begin{tabular}{|c|c|c|c|c|c|}
\hline & & & $\begin{array}{c}1.00= \\
Y\end{array}$ & $\begin{array}{c}2.00= \\
N\end{array}$ & Total \\
\hline & \multirow[t]{2}{*}{ Caucasian } & $\begin{array}{l}\text { Actual } \\
\text { Count }\end{array}$ & 126 & 270 & 396 \\
\hline & & $\begin{array}{l}\text { Expected } \\
\text { Count }\end{array}$ & 140.1 & 255.9 & 396.0 \\
\hline & \multirow[t]{2}{*}{ POC } & $\begin{array}{l}\text { Actual } \\
\text { Count }\end{array}$ & 71 & 90 & 161 \\
\hline & & $\begin{array}{l}\text { Expected } \\
\text { Count }\end{array}$ & 56.9 & 104.1 & 161.0 \\
\hline \multirow[t]{2}{*}{ Total } & & $\begin{array}{l}\text { Total } \\
\text { Count }\end{array}$ & 197 & 360 & 557 \\
\hline & & $\begin{array}{l}\text { Expected } \\
\text { Count }\end{array}$ & 197.0 & 360.0 & 557.0 \\
\hline
\end{tabular}

Note the corresponding hypothesis.

$\mathbf{H}_{2 \mathrm{I}}$ There is a difference in frequency of vicarious bullying based on race.

$\mathbf{H}_{20}$ There is no difference in frequency of vicarious bullying based on race.

Caucasians experienced vicarious bullying with less frequently than people of color. For this study, the term "people of color" pertained to all non-Caucasian participants who were 
black/African American, Latino/Hispanic, Asian/Pacific Islander, or multiple races. While 126 Caucasians actually reported experiencing vicarious bullying, according to the chi-square analysis, 140 affirmative responses to this question were expected. Conversely, 71 people of color experienced vicarious bullying, while the chi-square analysis stated that 56.9 was the expected count. Therefore, $\mathrm{H}_{21}$, "There is a difference in frequency of vicarious bullying based on race," is accepted.

The results of the chi-squared analysis pertaining to RQ3 "What is the difference is the frequency of vicarious bullying in American higher education based on gender?" are reported in Table 3.

Table 3

Frequency of Vicarious Bullying among Targets Grouped by Gender

\begin{tabular}{|c|c|c|c|c|c|}
\hline & & & $\begin{array}{l}1.00= \\
Y\end{array}$ & $\begin{array}{l}2.00= \\
\mathrm{N}\end{array}$ & Total \\
\hline & \multirow[t]{2}{*}{ Men } & $\begin{array}{l}\text { Actual } \\
\text { Count }\end{array}$ & 45 & 111 & 156 \\
\hline & & $\begin{array}{l}\text { Expected } \\
\text { Count }\end{array}$ & 55.2 & 100.8 & 156.0 \\
\hline & \multirow[t]{2}{*}{ Women } & $\begin{array}{l}\text { Actual } \\
\text { Count }\end{array}$ & 152 & 249 & 401 \\
\hline & & $\begin{array}{l}\text { Expected } \\
\text { Count }\end{array}$ & 141.8 & 259.2 & 401.0 \\
\hline \multirow[t]{2}{*}{ Total } & & $\begin{array}{l}\text { Total } \\
\text { Count }\end{array}$ & 197 & 360 & 557 \\
\hline & & $\begin{array}{l}\text { Expected } \\
\text { Count }\end{array}$ & 197.0 & 360.0 & 557.0 \\
\hline
\end{tabular}

Note the corresponding hypothesis:

$\mathbf{H}_{3 \mathbf{I}}$ There is a difference in frequency of vicarious bullying based on gender.

$\mathbf{H}_{30}$ There is no difference in frequency of vicarious bullying based on gender.

Men experienced vicarious bullying proportionally with less frequently than women. While 45 male respondents reported experiencing vicarious bullying, the chi- square analysis reported that 55.2 affirmative responses to this question were expected. On the other hand, 152 women reported vicarious bullying, while the chi-square analysis expected 141.8 affirmative responses for female participants. Therefore, $\mathrm{H}_{31}$, "there is a difference in frequency of vicarious bullying based on gender," is accepted.

The results of the chi-squared analysis pertaining to RQ4 "What is the difference in the frequency of vicarious bullying in American higher education based on sexual orientation?" are reported in Table 4. 
Table 4

Frequency of Vicarious Bullying among Targets Grouped by Sexual Orientation

\begin{tabular}{|c|c|c|c|c|c|}
\hline & & & $\begin{array}{l}1.00= \\
Y\end{array}$ & $\begin{array}{l}2.00= \\
\mathrm{N}\end{array}$ & Total \\
\hline & \multirow[t]{2}{*}{ Hetero } & $\begin{array}{l}\text { Actual } \\
\text { Count }\end{array}$ & 173 & 337 & 510 \\
\hline & & $\begin{array}{l}\text { Expected } \\
\text { Count }\end{array}$ & 181.3 & 328.7 & 510.0 \\
\hline & \multirow[t]{2}{*}{ LGBTQ } & $\begin{array}{l}\text { Actual } \\
\text { Count }\end{array}$ & 25 & 22 & 47 \\
\hline & & $\begin{array}{l}\text { Expected } \\
\text { Count }\end{array}$ & 16.7 & 30.3 & 47.0 \\
\hline \multirow[t]{2}{*}{ Total } & & $\begin{array}{l}\text { Total } \\
\text { Count }\end{array}$ & 198 & 359 & 557 \\
\hline & & $\begin{array}{l}\text { Expected } \\
\text { Count }\end{array}$ & 198.0 & 359.0 & 557.0 \\
\hline
\end{tabular}

Note the corresponding hypothesis.

$\mathbf{H}_{4 \mathrm{I}}$ There is a difference in frequency of vicarious bullying based on sexual orientation.

$\mathbf{H}_{40}$ There is no difference in frequency of vicarious bullying based on sexual orientation.

Heterosexual respondents experienced vicarious bullying with less expected frequently than the members of the LGBTQ community. While 173 heterosexual respondents reported experiencing vicarious bullying, the chi-square expected 181.3 affirmative responses to this question. In contrast, 25 LGBTQ community members reported vicarious bullying, while the chi-square analysis reported that 16.7 was the expected count. Therefore, $\mathrm{H}_{41}$, "There is a difference in frequency of vicarious bullying based on sexual orientation," is accepted.

The results of the chi-squared analysis pertaining to RQ5 "What is the difference is the frequency of vicarious bullying in American higher education based on age?" are reported in Table 5.

Table 5

Frequency of Vicarious Bullying among Targets Grouped by Age

\begin{tabular}{|c|c|c|c|c|c|}
\hline & & & $\begin{array}{c}1.00= \\
Y\end{array}$ & $\begin{array}{c}2.00= \\
\mathrm{N}\end{array}$ & \\
\hline & \multirow[t]{2}{*}{$\begin{array}{l}\text { Ove } \\
\text { r } 35\end{array}$} & $\begin{array}{l}\text { Actual } \\
\text { Count }\end{array}$ & 196 & 260 & 456 \\
\hline & & $\begin{array}{l}\text { Expected } \\
\text { Count }\end{array}$ & 192.4 & 263.6 & 456.0 \\
\hline & \multirow[t]{2}{*}{$\begin{array}{l}\text { Under } \\
35\end{array}$} & $\begin{array}{l}\text { Actual } \\
\text { Count }\end{array}$ & 39 & 62 & 101 \\
\hline & & $\begin{array}{l}\text { Expected } \\
\text { Count }\end{array}$ & 42.6 & 58.4 & 101.0 \\
\hline \multirow[t]{2}{*}{ Total } & & $\begin{array}{l}\text { Total } \\
\text { Count }\end{array}$ & 235 & 322 & 557 \\
\hline & & $\begin{array}{l}\text { Expected } \\
\text { Count }\end{array}$ & 235.0 & 322.0 & 557.0 \\
\hline
\end{tabular}

Note the corresponding hypothesis.

$\mathbf{H}_{5 \mathrm{I}}$ There is a difference in frequency of vicarious bullying based on age.

$\mathbf{H}_{50}$ There is no difference in frequency of vicarious bullying based on age. 
Respondents aged 36 years or older experienced vicarious bullying proportionally with slightly more frequency than those aged 35 and younger. While 173 respondents aged 36 years or older reported vicarious bullying, the chi-square analysis reported 192.4 affirmative responses to this question. In contrast, 39 respondents under 35 reported vicarious bullying, while 42.6 was the expected count. Therefore, $\mathrm{H}_{50}$, "There is no difference in frequency of vicarious bullying based on age," is rejected because there is a slight difference in frequency regarding age.

\section{PRACTICAL IMPLICATIONS}

Workplace bullying has received more attention in research circles since the 1990s (Branch et al., 2013; Cowan, 2012; Fritz, 2014; Hollis \& McCalla, 2013, Zabrodska \& Kveton, 2013). Some researchers considered the psychological impact, while others focused on the cost and damage to the institution. However, the role and impact of vicarious bully has not been previously explored. Nonetheless, these findings showed that just over a third of the respondents were targeted by vicarious bullying. Thus, not addressing this type of bullying, or not recognizing it, can create tension throughout the organization. Moreover, vicarious bullying can intensify the acceptance of bullying behaviors throughout the organization.

The findings yielded by the present investigation showed that members of disenfranchised populations, such as people of color, women, and the LGBTQ individuals, face vicarious bullying with more frequency. Workplace bullying is a product of a power differential (Goldblatt, 2007). Vicarious bullying occurs when a more powerful person has a subordinate at his or her disposal to dispatch in this henchman/henchwoman capacity. The data reported in this work showed that less powerful disenfranchised populations are more likely to be the target of vicarious bullying as women and people of color are less likely to hold executive and leadership positions.

These findings would thus have implications for diversity management. The underrepresented groups in this study, women, people of color, and the LGBTQ community members are more likely to face the bully's henchmen. As a result, they are more likely to disengage from the work environment or leave the work environment, taking with them their valuable contributions. Further, as the higher education sector is serving more women, people of color, and the LGBTQ community, diverse role models are increasingly important to serve and represent all members of the higher education community. However, such representation is compromised when these populations disproportionally face the bully's henchmen.

\section{RECOMMENDATIONS AND CONCLUSION}

Vicarious bullying is a complex issue, as it involves two aggressors, the bully and the henchmen. Human Resources professionals might consider the henchman as the bully's target, as he/she may be coerced into acting as the aggressor on behalf of the bully. Consequently, interventions aimed at bullying prevention should include an assessment of the henchmen's position and consider how that person may have been strong-armed into this behavior.

1) Many organizations are starting to create anti-bullying policies. Such policies should be expanded to encompass third-party or vicarious bullying. Since 35\% of respondents experienced this complex style of bullying, managers, supervisors, and colleagues should be aware of this phenomenon and be trained on how to mitigate this dynamic.

2) Training and intervention can help targets recognize this style of bullying and differentiate it from the direct one-on-one bullying. Training and interventions should also be provided to the potential "henchmen" so that they can realize that they can be culpable if they engage in bullying. Potential henchmen should also be reassured that 
they will not face retaliation due to reporting a bully who employs third parties to engage in bullying.

3) Campus climate surveys can give an anonymous voice to those dealing with direct or vicarious bullying. The key to successful administration of these surveys is that the organization needs to seriously consider reports of bullying to build and maintain trust throughout the organization. Employees find such surveys frustrating when their honest concerns are not seriously considered.

Employee relations and management has become increasingly complex as the workplace has become more diverse. This complexity also incorporates bullying and its deleterious impact on staff. As this analysis showed, disenfranchised populations disproportionally face vicarious bullying; hence, managers and supervisors should be aware of this bullying strategy and must avoid discounting reports of this harmful behavior.

\section{CONCLUSION}

As noted in several studies (Bernard, 2017; Branch, Ramsay, \& Barker, 2013; Einarsen e.t al, 2016; Fritz, 2014; Goldblatt, 2007; Hollis, 2016c) workplace bullying relies on a power differential. Those who have power have the latitude to demoralize and abuse those with less power. The abuse of power leads to disengaged staff, costly turnover, and lower productivity. While workplace bullying is still an emerging issue in the United States, human resources staff and leadership should consider not only the complex dynamics of bullying but recognize that even third party bullying, that is the higher educational henchman, is destructive to workplace morale.

\section{References}

Bernard, A. (2017). Beyond the wheelchair. Workplace bullying and persons with disabilities. Global Journal of Arts, Humanities and Social Sciences, 5 (3). 41-47

Bernays, E. L. (2001). Viewpoint: The Case for Licensing PR Practitioners. Public Relations Quarterly, 28 (1), p.32.

Bond, S. A., Tuckey, M. R., \& Dollard, M. F. (2010). Psychosocial safety climate, workplace bullying, and symptoms of posttraumatic stress. Organization Development Journal, 28 (1), pp. 37-56.

Branch, S., Ramsay, S. \& Barker, M. (2013). Workplace Bullying, Mobbing and General Harassment: A Review. International Journal of Management Reviews. pp. 280-299. doi:10.1111/j.1468-2370.2012.00339.

Byrne, Z.S., (2014). Understanding employee engagement: Theory, research, and practice. New York, NY. Routledge.

Cowan, R. (2012). It's Complicated: Defining workplace bullying from the human resource professional's perspective. Management Communication Quarterly. 3. pp. 377-403. Doi: 10.1177/0893318912439474.

Dictionary, O. (2014). Oxford dictionaries. Language Matters.

Einarsen, S., Hoel, H., Zapf, D., \& Cooper, C. (2011). Bullying and harassment in the workplace. Boca Raton, FL: CRC Press.

Einarsen, S., Skogstad, A., Rørvik, E., Lande, Å. B., \& Nielsen, M. B. (2016). Climate for conflict management, exposure to workplace bullying and work engagement: a moderated mediation analysis. The International Journal of Human Resource Management, 1-22.

Erkutlu, H., \& Chafra, J. (2014). Ethical leadership and workplace bullying in higher education. Hacettepe University Journal of Education, 29, 55-67.

Fritz, J. (2014). Organizational misbehavior bullying in the workplace: causes symptoms, and remedies. Ed. John Lipinski \& Laura Crothers. New York, NY: Routledge Taylor \& Francis.

Getty, J. A. (2013). Practicing Stalinism: Bolsheviks, boyars, and the persistence of tradition. Yale University Press. Goldblatt, V. (2007). Bye-bye bullies: How to get people to want to work. New Zealand Management, 54(4), 39-41. 
Hollis, L. P., \& McCalla, S. A. (2013). Bullied back in the closet. Journal of Psychological Issues in Organizational Culture, 4(2), 6-16.

Hollis, L. P. (2016). Bruising the Bottom Line: Cost of Workplace Bullying and the Compromised Access for Underrepresented Community College Employees. In Hollis, L.P. (Ed.) In The Coercive Community College: Bullying and its Costly Impact on the Mission to Serve Underrepresented Populations. Emerald Group Publishing Limited. United Kingdom. pp. 1-26

Hollis, L.P. (2016a). Canary in the mine: ombuds as first alerts for workplace bullying on campus. Journal of International Ombudsman Association. 9. (1). pp. 23- 31.

Hollis, L. P. (2016b). Cybershaming-Technology, Cyberbullying, and the Application to People of Color. In Hollis, L.P. (Ed.) In The Coercive Community College: Bullying and its Costly Impact on the Mission to Serve Underrepresented Populations. Emerald Group Publishing Limited. United Kingdom. pp. 125-135.

Hollis, L. P. (2016c). Socially Dominated: The Racialized and Gendered Positionality of Those Precluded from Bullying. In The Coercive Community College: Bullying and its Costly Impact on the Mission to Serve Underrepresented Populations (pp. 103-112). Emerald Group Publishing Limited.

Hughes, J. J. (2012). Nazis on the run: How hitler's henchmen fled justice. The Catholic Historical Review, 98 (1), pp. 150-151.

Keashly, L., \& Neuman, J. H. (2010). Faculty experiences with bullying in higher education: Causes, consequences, and management. Administrative Theory \& Praxis, 32 (1), pp. 48-70.

Jolliffe, D. \& Farrington, D.P., (2006). Examining the relationship between low empathy and bullying. Aggressive behavior. 32 (6). pp.540-550.

Rodríguez-Muñoz, A., Notelaers, G., \& Moreno-Jiménez, B. (2011). Workplace bullying and sleep quality: The mediating role of worry and need for recovery.\Behavioral Psychology/ Psicologia Conductual, 19 (2), pp. 453468.

Ryan, M. (2016). Besting the workplace bully. Reference \& User Services Quarterly, 55 (4), pp. 267-269.

Simpson, R., \& Cohen, C. (2004). Dangerous work: The gendered nature of bullying in the context of higher education. Gender, Work \& Organization. 11 (2), pp. 163-186.

Steinacher, G. (2012). Nazis on the Run: How Hitler's Henchmen Fled Justice. Oxford University Press.

Strathern, A. (1993). Violence and political change in papua new guinea. Bijdragen Tot De Taal-, Land-En Volkenkunde, 149 (4), p. 718.

Thomas, M. (2005). Bullying among support staff in a higher education institution. "Health Education, 105, pp. 273-288.

Zabrodska, K., \& Kveton, P. (2013). Prevalence and forms of workplace bullying among university employees. Employee Responsibilities and Rights Journal. pp. 89-108. 10.1007/s10672-012-9210-x 